\section{Onset of Inflammatory Eye Disease Under Tocilizumab Treatment for Rheumatologic Conditions: A Paradoxical Effect?}

To the Editor:

Tocilizumab (TCZ), a monoclonal antibody directed against interleukin 6 (IL-6) receptor, exerts powerful inhibition of IL-6 and demonstrates antiinflammatory properties. This biologic agent is used in chronic inflammatory diseases ${ }^{1}$. We describe 2 cases of onset of inflammatory eye disease under TCZ therapy.

Case 1. A 41-year-old man with defined axial HLA-B27-positive ankylosing spondylitis (AS, according to the modified New York criteria ${ }^{2}$ ) for 8 years was refractory to nonsteroidal antiinflammatory drugs, steroids, pamidronate, and 3 tumor necrosis factor (TNF) blockers (infliximab, etanercept, adalimumab). TCZ was initiated ( $8 \mathrm{mg} / \mathrm{kg}$ per month). Between the second and third infusion, a first episode of acute anterior uveitis occurred. Investigations for infection, including polymerase chain reaction in aqueous humor, were negative. Outcome was favorable under local and general steroids and continuation of TCZ. Ankylosing Spondylitis Disease Activity Score decreased from 5.0 to 3.5 , and C-reactive protein from 35 to $3 \mathrm{mg} / \mathrm{l}$ during this period.

Case 2. A 65-year-old man with erosive rheumatoid factor-positive and anti-citrullinated protein antibody-positive rheumatoid arthritis (RA) of 10 years' duration, without Sjögren's syndrome, refractory to conventional disease-modifying antirheumatic drugs, was treated with TCZ $(8 \mathrm{mg} / \mathrm{kg} / 4$ weeks) with good response (70\% reduction in joint counts, and reduction of prednisone intake from 5 to $2 \mathrm{mg}$ /day). After 11 months of TCZ, he had a first episode of peripheric ulcerative keratitis with eosinophilia (1293 $\mathrm{g} / \mathrm{l}$ ). Infection was ruled out, and TCZ delayed (one month) with favorable outcome under local treatment (antiinflammatory and antibiotic eye drops). Relapse of keratitis occurred 20 days after the third new infusion. TCZ was then held for 2 months. After reintroduction of TCZ (19 days), a third episode of keratitis occurred. TCZ was then stopped.

In these 2 cases, ocular inflammation occurred de novo under TCZ treatment for chronic inflammatory diseases, whereas biologic inflammation was normalized, and patients responded to the treatment. Other causes of inflammation were excluded (particularly infection). Inflammatory eye disease may be an extraarticular feature of the disease (uveitis in AS, and keratitis in RA), but the patients did not experience such manifestations before TCZ treatment, and it occurred in a period of control of systemic inflammation. Moreover, in the second case, the rechallenge test was positive.

This may represent a new example of a paradoxical effect of biologic agents, as suggested for TNF blockers, which may induce new onset of uveitis $^{3}$ or scleritis ${ }^{4}$ in cases of rheumatic diseases controlled by this treatment.

IL-6 plays an important role in development of uveitis ${ }^{5,6}$, with increased levels of this cytokine in serum and aqueous humor in acute cases. In experimental models of uveitis, IL-6 blockade with a monoclonal antibody directed against IL-6 receptor improves uveitis by suppressing systemic and local Th17 response ${ }^{7,8}$. Nevertheless, it has been demonstrated that levels of soluble gp130, an antagonist of IL- 6 trans-signaling, were not different in the serum of patients with active uveitis and controls, whereas levels were significantly elevated in aqueous humor of patients with severe uveitis ${ }^{9}$. Moreover, IL-6 may have a protective role in some kinds of keratitis ${ }^{10}$.

Paradoxical eye inflammation may occur under IL-6 blockade in inflammatory arthritis.

DANIEL WENDLING, MD, PhD, Professor of Rheumatology, University Hospital, Departmet of Rheumatology, Besançon; EMMANUELLE DERNIS, MD, Department of Rheumatology, General Hospital Le Mans; CLÉMENT PRATI, MD; University Hospital, Department of Rheumatology, Besançon; ERIC FRISCH, MD, Private office in Ophthalmology, Le Mans; BERNARD DELBOSC, MD, Professor of Ophthalmology, University Hospital, Department of Ophthalmology, Besançon, France. Address correspondence to Prof. Wendling;

E-mail:dwendling@chu-besancon.fr

\section{REFERENCES}

1. Pham T, Claudepierre P, Constantin A, de Bandt M, Fautrel B, Gossec L, et al. Tocilizumab: therapy and safety management. Joint Bone Spine 2010;77 Suppl 1:S3-100.

2. van der Linden S, Valkenburg HA, Cats A. Evaluation of diagnostic criteria for ankylosing spondylitis. A proposal for modification of the New York criteria. Arthritis Rheum 1984;27:361-8.

3. Wendling D, Paccou J, Flipo RM, Dernis E, Direz G, Ferrazzi V, et al. New onset of uveitis under anti TNF therapy. A nationwide series [abstract]. Arthritis Rheum 2010;62 Suppl:S374-375.

4. Gaujoux-Viala C, Giampietro C, Gaujoux T, Ea HK, Orcel P, Lioté F. A new paradoxical effect of etanercept? A series of 3 cases and systematic literature review of etanercept-associated inflammatory eye disease [abstract]. Arthritis Rheum 2010;62 Suppl:S174.

5. Kramer M, Monselise Y, Bahar I, Cohen Y, Weinberger D, Goldenberg-Cohen N. Serum cytokine levels in active uveitis and remission. Curr Eye Res 2007;32:669-75.

6. Xu Y, Chen W, Lu H, Hu X, Li S, Wang J, et al. The expression of cytokines in the aqueous humor and serum during endotoxin-induced uveitis in $\mathrm{C} 3 \mathrm{H} / \mathrm{HeN}$ mice. Mol Vis 2010;16:1689-95

7. Hohki S, Ohguro N, Haruta H, Nakai K, Terabe F, Serada S, et al. Blockade of interleukin-6 signaling suppresses experimental autoimmune uveoretinitis by the inhibition of inflammatory Th17 responses. Exp Eye Res 2010;91:162-70.

8. Yoshimura T, Sonoda KH, Ohguro N, Ohsugi Y, Ishibashi T, Cua DJ, et al. Involvement of Th17 cells and the effect of anti-IL-6 therapy in autoimmune uveitis. Rheumatology 2009;48:347-54.

9. Simon D, Denniston AK, Tomlins PJ, Wallace GR, Rauz S, Salmon M, et al. Soluble gp130, an antagonist of IL-6 transsignaling, is elevated in uveitis aqueous humor. Invest Ophthalmol Vis Sci 2008:49:3988-91

10. Hume EB, Cole N, Garthwaite LL, Khan S, Willcox MD. A protective role for IL-6 in staphylococcal microbial keratitis. Invest Ophthalmol Vis Sci 2006;47:4926-30.

J Rheumatol 2011;38:10; doi:10.3899/jrheum.110170 